\title{
Effects of High Shearing Rates on the Shear Behavior of Saturated Loess Using Ring Shear Tests
}

\author{
Jianquan Ma $\mathbb{D}^{1,}, 2$ Xiaojie Zhao, ${ }^{1}$ Shibo Li $\mathbb{D}^{1},{ }^{1}$ and Zhao Duan $\mathbb{D}^{1}$ \\ ${ }^{1}$ College of Geology and Environment, Xi'an University of Science and Technology, Xi'an 710054, China \\ ${ }^{2}$ Key Laboratory of the Northern Qinghai-Tibet Plateau Geological Processes and Mineral Resources, Qinghai Geological \\ Survey Institute, Xining 810012, China
}

Correspondence should be addressed to Zhao Duan; duanzhao@xust.edu.cn

Received 17 June 2021; Revised 3 August 2021; Accepted 26 August 2021; Published 11 September 2021

Academic Editor: Zhongqiong Zhang

Copyright (C) 2021 Jianquan Ma et al. This is an open access article distributed under the Creative Commons Attribution License, which permits unrestricted use, distribution, and reproduction in any medium, provided the original work is properly cited.

\begin{abstract}
The shear behavior of saturated loess was examined by performing a series of ring shear tests with different shearing rates. The effects of shearing rates on the shear behavior of saturated loess with different normal stress are presented and discussed. The results showed that peak shear strength and steady-state shear strength were greater when the shearing rate was low and vice versa. Compared with high and low shearing rates, the maximum strength reduction ratios of peak shear strength and steadystate shear strength were $34.2 \%$ and $37.2 \%$, respectively. The axial displacement during shearing was measured and was found to increase with increasing shear displacement in all tests. A comparison of sample height reduction (when the shear rate was stopped) found that the low shearing rate test sample underwent a much greater reduction than the high shearing rate test sample; however, the variation reduction range was within $4 \mathrm{~mm}$. Monitoring the pore-water pressure during the shearing process revealed that it increased with shear displacement, and a higher excess pore-water pressure was generated within the shear zone during the fast-shearing process. Comparing the particle size distribution of the samples after the test and the original sample showed that the particles were crushed during the shearing process. The percentage that was finer than $0.005 \mathrm{~mm}$ increased with shearing rates and normal stress, and the soil structure implosion became more pronounced with increasing normal stress.
\end{abstract}

\section{Introduction}

The loess flowslide is an important disaster type in the Loess Plateau, and various factors can induce such landslides $[1,2]$. Loess landslides have high speed and long runout characteristics $[3,4]$. Generally, rapid reduction of the peak shear strength of the slip zone soil to the residual shear strength is the mechanism of high-speed landslides [5]. The residual strength of the slip zone soil can be measured using reversal shear, triaxial compression, and ring shear tests. Compared with reversal direct shear and triaxial compression tests, ring shear tests have been preferentially adopted to determine the residual shear strength of soil, due to their ability to shear unlimited displacements [6-8]. Many factors, such as shearing rate, moisture content, surface roughness, consolidated state, and temperature, affect the magnitude of the residual soil strength [9-16]. Among these factors, the loss of strength caused by the shearing rate (greater than $100 \mathrm{~mm} / \mathrm{min}$ ) explains the high acquired velocity of landslides [17, 18].

From the high shearing rate aspect found in the literature, Hunger and Morgenstern [19] determined that the perfect frictional behavior was observed in all shearing tests with shearing rates of $16.0 \mathrm{~cm} / \mathrm{s}$ and $98.2 \mathrm{~cm} / \mathrm{s}$, which were not influenced by the shearing rate or normal stress. Sassa and Fukuoka [20] found that the friction angle in granular materials varied from $-3.2^{\circ}$ to $+3.7^{\circ}$ at different shearing rates of $0.01 \mathrm{~cm} / \mathrm{s}$ to $100 \mathrm{~cm} / \mathrm{s}$. For clay materials, the effect of the shearing rate on the test results was different from that of granular materials. Tika et al. [21] identified three types of rate effects on residual strength: a positive rate effect (fast residual strength higher than slow residual strength), a neutral rate effect (constant fast residual strength equal to slow residual strength), and a negative rate effect (a significant drop in fast residual strength below slow residual strength 


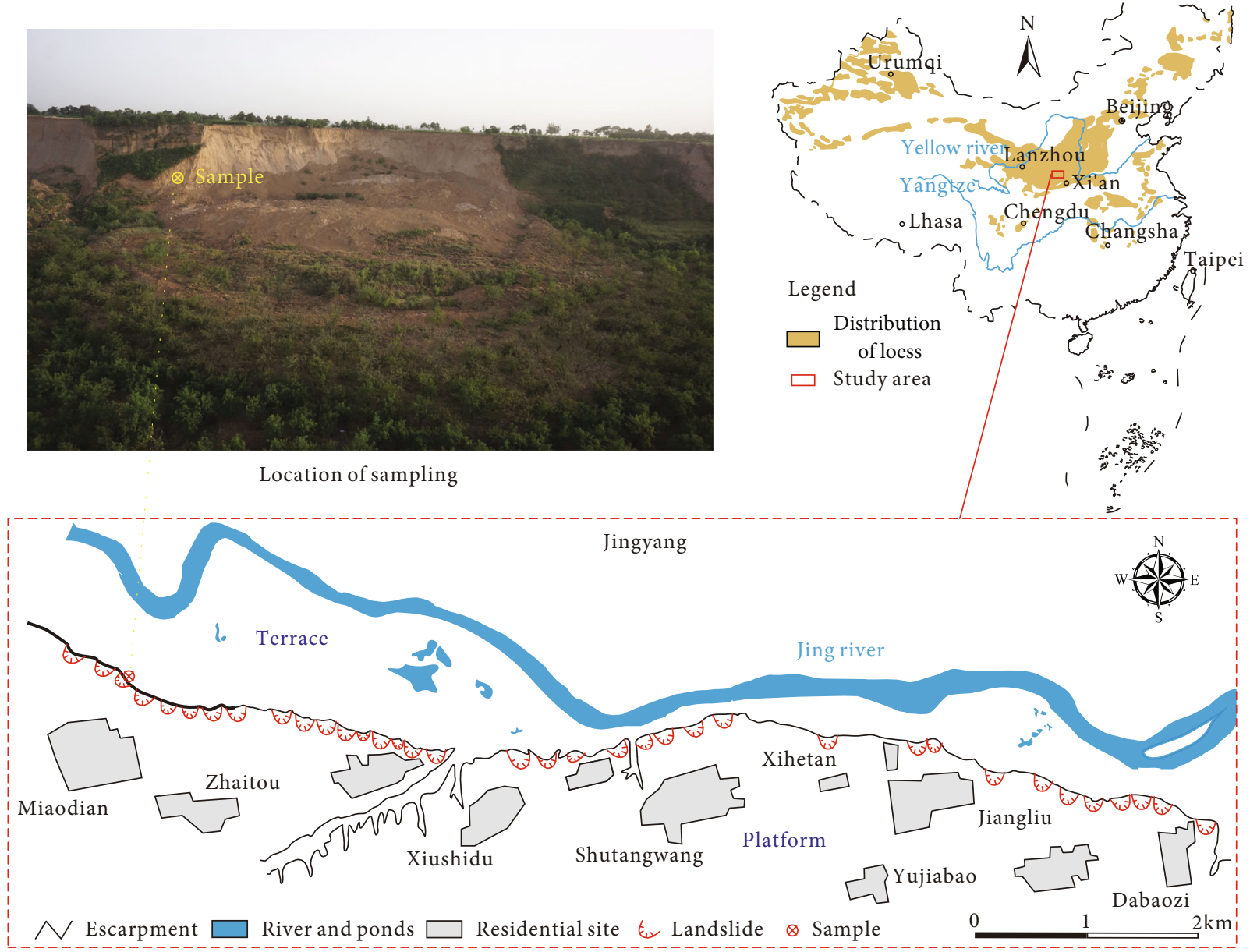

FIgURE 1: Location of sampling and map of landslides.

when sheared at rates higher than the critical value). Tika and Hutchinson [18] found that clay samples showed a significant loss of strength, up to $60 \%$ below the slow residual strength, when sheared at rates greater than $100 \mathrm{~mm} / \mathrm{min}$. Lian et al. [8] also found differences in the residual strength of samples with shearing rates of $1-3 \mathrm{rev} / \mathrm{min}$.

The majority of previous studies have examined the residual strength or liquefaction behavior of saturated clay and sand or granular materials using ring shear tests [22-27]. However, except for a few studies $[6,8,28]$, there are relatively limited studies on the shear behavior of saturated loess using ring shear tests. Exploring the shear behavior of the saturated slip zone loess with high shearing rates (greater than $100 \mathrm{~mm} / \mathrm{min}$ ) and different normal stress using ring shear tests has rarely been undertaken in the geotechnical literature.

In the present study, the shear behavior of saturated loess from the slip zone was examined by performing a series of ring shear tests with different shearing rates to provide useful information for landslide mechanism analysis. First, peak shear strength, steady-state shear strength, height reduction of samples, and pore-water pressure were analyzed and discussed under shearing rates of 131, 262, and $393 \mathrm{~mm} / \mathrm{min}$ and normal stresses of 100,200 , and $300 \mathrm{kPa}$.
TABLE 1: Sample properties.

\begin{tabular}{lc}
\hline Soil properties & Values \\
\hline Natural water content $(\%)$ & 7.4 \\
Dry density $\left(\mathrm{g} \bullet \mathrm{cm}^{-3}\right)$ & 1.48 \\
Specific gravity, $G_{\mathrm{s}}$ & 2.71 \\
Liquid limit $(\%)$ & 26.4 \\
Plastic limit (\%) & 16.1 \\
Plasticity index & 10.3 \\
Unified Soil Classification System & $\mathrm{CL}$ \\
\hline
\end{tabular}

Then, the effects of the different shearing rates and normal stress on particle size and crushing were discussed using the particle size distribution (PSD) of samples after the tests.

\section{Materials and Methods}

2.1. Sample Characteristics. The loess tested was taken from the southern Jingyang platform on the southeast margin of the Chinese Loess Plateau (Figure 1). Approximately 50 landslides involving loess flowslides and loess slides have occurred here since the irrigation of this platform began in $1976[29,30]$. Field investigations indicate that the sliding 


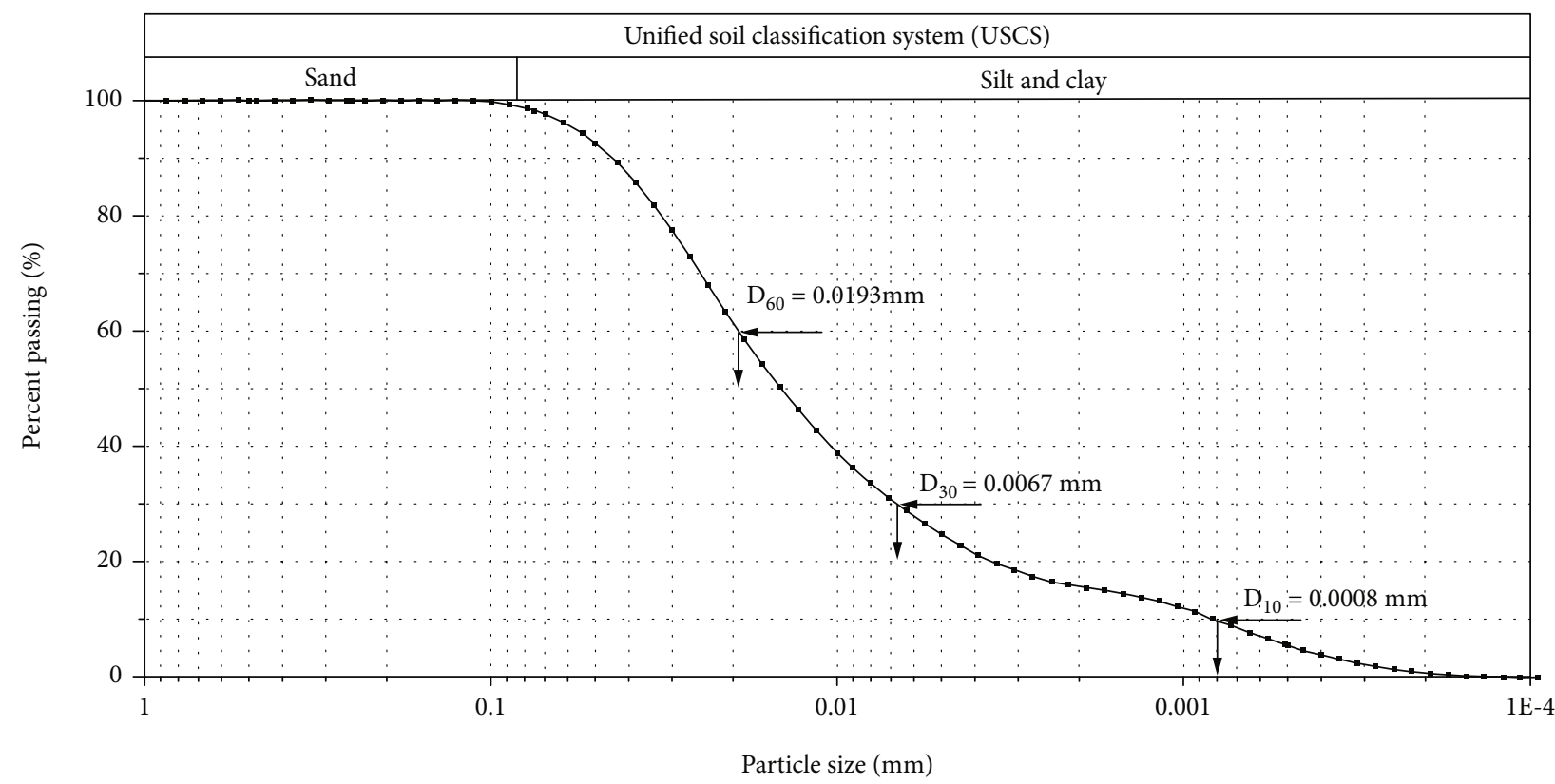

Figure 2: Particle size distributions of samples $\left(D_{10}, D_{30}\right.$, and $D_{60}$ are the particle sizes corresponding to $10 \%, 30 \%$, and $60 \%$ finer materials on the cumulative particle size distribution curve, respectively).

surface of the landslide was mainly developed in the Quaternary loess sedimentary strata [31]. Thus, loess samples were collected from the adjacent strata at the Miaodian landslide site of the Jingyang platform [32].

The physical properties listed in Table 1 were obtained following ASTM International procedures. The natural water content of the samples was $7.4 \%$, and the dry density was $1.48 \mathrm{~g} / \mathrm{cm}^{3}$. The liquid limit and plastic limit of the sample were $26.4 \%$ and $16.1 \%$, respectively; therefore, the calculated plasticity index was 10.3. According to the ASTM D2487 [33], the soil classification was lean clay (CL). The PSDs of the samples were measured using a Bettersize2000 laser particle size analyzer (Bettersize Instruments Ltd., China) and are shown in Figure 2. The minimum resolution of the PSD measuring equipment was $0.02 \mu \mathrm{m}$, and the measuring principle used was the Mie scattering theory. The effective size $\left(D_{10}\right)$ was $0.8 \mu \mathrm{m}$, the $D_{30}$ value (diameter corresponding to $30 \%$ finer material) was $6.7 \mu \mathrm{m}$, and the $D_{60}$ value (diameter corresponding to $60 \%$ finer material) was $19.3 \mu \mathrm{m}$. The clay content (grain size $<0.005 \mathrm{~mm}$ ) of the sample was $24.8 \%$, the silt content (grain size $=0.075 \mathrm{~mm}-$ $0.005 \mathrm{~mm}$ ) was $73.4 \%$, and the sand content (grain size $>0.075 \mathrm{~mm}$ ) was $1.8 \%$.

2.2. Test Apparatus and Procedures. The ring shear apparatus GCTS SRS-150 was used in the present study, which can apply shearing rates ranging from 0.001 to $360 \mathrm{deg} / \mathrm{min}$ continuously without backlash to replicate true in situ strain rates during failure. The apparatus can accept $150 \mathrm{~mm}$ outer diameter, $100 \mathrm{~mm}$ inner diameter, and $30 \mathrm{~mm}$ height annular specimens $\left(98 \mathrm{~cm}^{2}\right.$ effective sample area).

Remolded samples were prepared for the ring shear experiments. The samples were air-dried, crushed, and passed through a $2 \mathrm{~mm}$ sieve. Then, distilled water was sprayed on the sieved soil until a moisture content of $31 \%$
TABLE 2: Ring shear test program of the loess samples.

\begin{tabular}{|c|c|c|c|c|}
\hline \multirow{2}{*}{$\begin{array}{l}\text { Shearing rate }(\mathrm{deg} / \mathrm{min}(\mathrm{mm} / \\
\text { min)) }\end{array}$} & \multicolumn{3}{|c|}{$\begin{array}{c}\text { Normal stress } \\
\text { level }(\mathrm{kPa})\end{array}$} & \multirow[t]{2}{*}{ Shearing method } \\
\hline & 100 & 200 & 300 & \\
\hline $120(131)$ & $\begin{array}{c}\mathrm{RS} \\
1\end{array}$ & $\mathrm{RS}_{-}$ & $\mathrm{RS}_{3}$ & $\begin{array}{l}\text { Single-stage } \\
\text { shearing }\end{array}$ \\
\hline $240(262)$ & $\mathrm{RS}_{-}$ & $\mathrm{RS}_{5}$ & $\mathrm{RS}_{-}$ & $\begin{array}{l}\text { Single-stage } \\
\text { shearing }\end{array}$ \\
\hline $360(393)$ & $\mathrm{RS}_{-}$ & $\mathrm{RS}_{8}$ & $\mathrm{RS}_{9}$ & $\begin{array}{l}\text { Single-stage } \\
\text { shearing }\end{array}$ \\
\hline
\end{tabular}

TABLE 3: Summary of ring shear test results.

\begin{tabular}{lcccccc}
\hline \multirow{2}{*}{$\begin{array}{l}\text { Test } \\
\text { number }\end{array}$} & \multicolumn{2}{c}{ Shearing condition } & \multicolumn{4}{c}{ Shearing state value } \\
& $\begin{array}{c}\text { Shearing rate } \\
(\mathrm{mm} / \mathrm{min})\end{array}$ & $\begin{array}{c}\text { Normal } \\
\text { stress }(\mathrm{kPa})\end{array}$ & $\begin{array}{c}\tau_{\mathrm{p}} \\
(\mathrm{kPa})\end{array}$ & $\begin{array}{c}\tau_{\mathrm{s}} \\
(\mathrm{kPa})\end{array}$ & $\begin{array}{c}u_{\mathrm{p}} \\
(\mathrm{kPa})\end{array}$ & $\begin{array}{c}h_{\mathrm{a}} \\
(\mathrm{mm})\end{array}$ \\
\hline RS_1 & 131 & 100 & 63.3 & 57.5 & 6.20 & 2.031 \\
RS_2 & 131 & 200 & 114.5 & 109.1 & 7.00 & 2.722 \\
RS_3 & 131 & 300 & 172.7 & 167.0 & 7.74 & 3.541 \\
RS_4 & 262 & 100 & 56.6 & 50.6 & 7.50 & 1.392 \\
RS_5 & 262 & 200 & 101.5 & 92.6 & 7.92 & 2.107 \\
RS_6 & 262 & 300 & 149.2 & 128.1 & 8.32 & 2.826 \\
RS_7 & 393 & 100 & 49.4 & 36.1 & 9.30 & 1.257 \\
RS_8 & 393 & 200 & 79.3 & 68.2 & 9.79 & 1.922 \\
RS_9 & 393 & 300 & 113.7 & 104.5 & 11.50 & 2.372 \\
\hline
\end{tabular}

$\tau_{\mathrm{p}}$ : peak shear strength; $\tau_{\mathrm{s}}$ : shear strength at steady state; $u_{\mathrm{p}}, h_{\mathrm{a}}:$ pore-water pressure and axial displacement when the shear was stopped.

(almost saturated moisture content) was obtained. Samples with the desired moisture content were kept in a plastic bag and placed in a sealed conditioner for approximately $48 \mathrm{~h}$ to obtain uniformity. The reconstituted samples were 


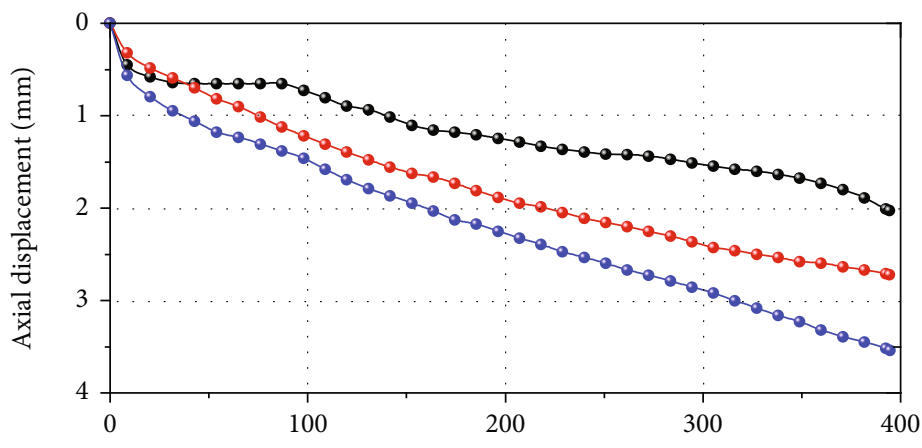

Shear displacement $(\mathrm{mm})$

(a)

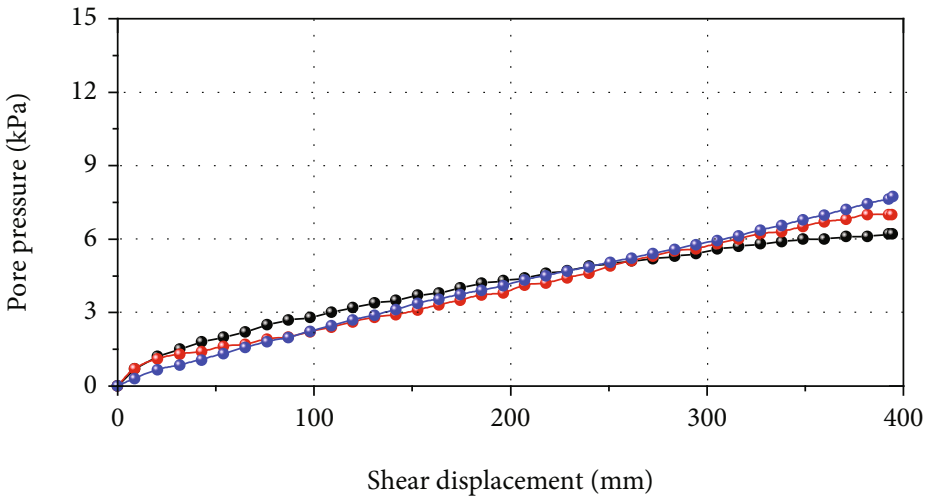

(b)

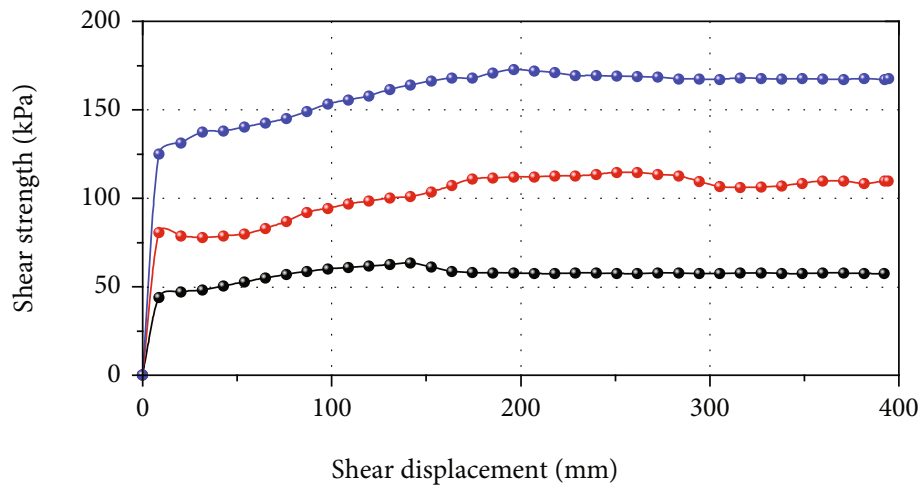

$\multimap$ RS_1 $100 \mathrm{kPa}$
$\multimap$ RS_2 200kPa
$\multimap$ RS_3 300kPa

(c)

FIGURE 3: Results of ring shear tests with a shearing rate of $131 \mathrm{~mm} / \mathrm{min}$.

evenly filled in the shear box using a spatula and compacted for all test series. The dry density of the samples in the shear box was maintained at $1.4 \mathrm{~g} / \mathrm{cm}^{3}$. Prior to shearing, the consolidation pressure was set to one-time loading. The consolidation of specimens lasted for at least $24 \mathrm{~h}$ until the axial settlement rate was $<0.01 \mathrm{~mm} / \mathrm{min}$.

The ring shear test program is shown in Table 2. The single-stage ring shear test procedure on the drain condition was followed. Nine ring shear tests were conducted under normal stresses of 100,200 , and $300 \mathrm{kPa}$ and shearing rates of 120,240 , and $360 \mathrm{deg} / \mathrm{min}(131,262$, and $393 \mathrm{~mm} / \mathrm{min})$ in the present study.

\section{Results and Analysis}

In the test series, all samples were sheared to a displacement of $400 \mathrm{~mm}$. The tests presented here illustrate the shearing rate effects on the shear behavior of saturated loess under different normal stresses. The effects were seen clearly from the test results. All test results are summarized in Table 3. 


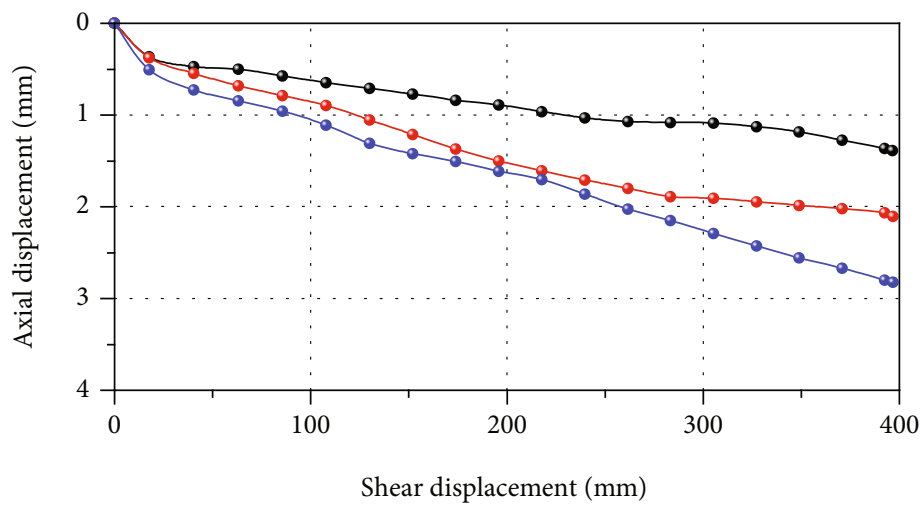

(a)

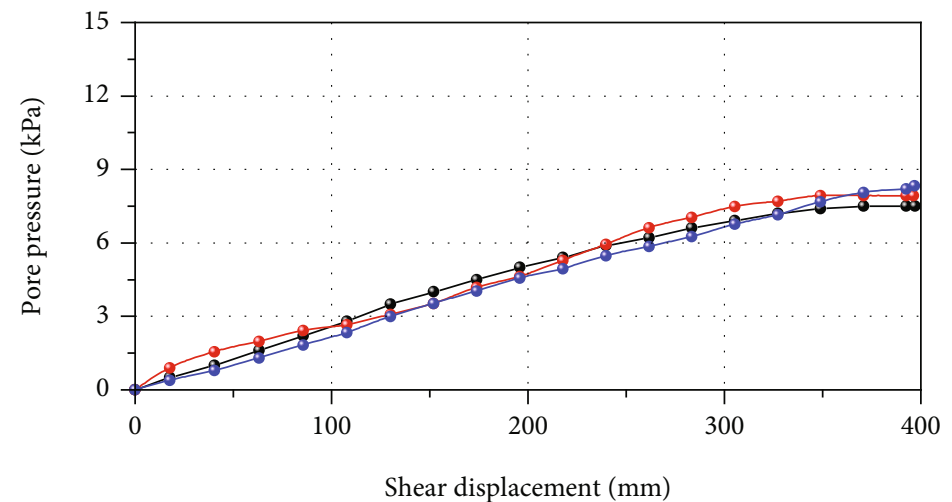

(b)

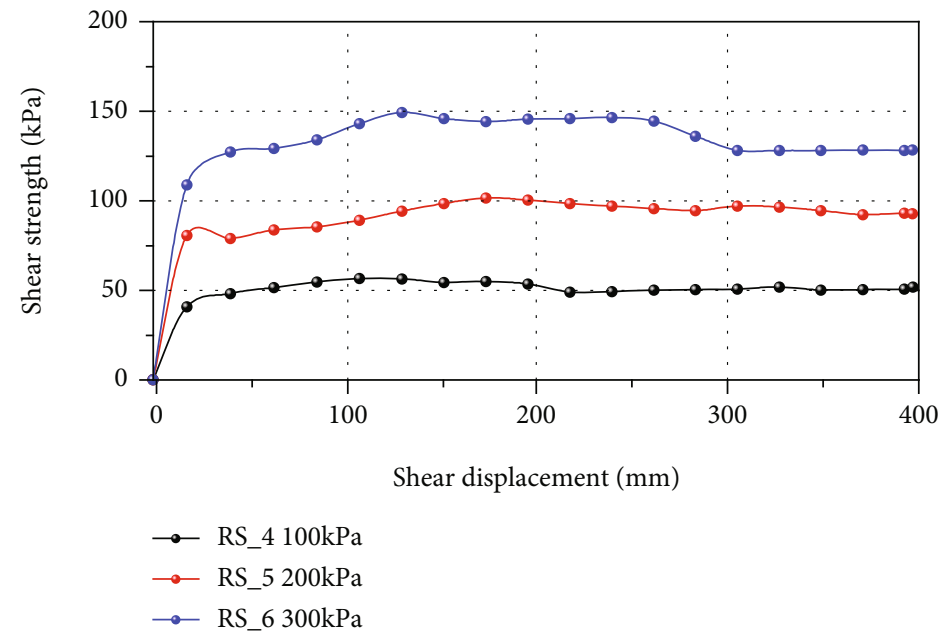

(c)

Figure 4: Results of ring shear tests with a shearing rate of $262 \mathrm{~mm} / \mathrm{min}$.

The results at shearing rates of 131, 262, and $393 \mathrm{~mm} / \mathrm{min}$ are shown in Figures 3-5, where the axial displacement, pore-water pressure, and shear strength were plotted against shear displacements at different shearing rates.

The axial displacement gradually increased with shear displacement (Figure 3(a)). The axial displacement response was almost the same for the other shearing rate tests (Figures 4(a) and 5(a)). The greater the normal stress, the greater the axial displacement. However, under the same normal stress, the higher the shearing rate, the lower the axial displacement. The final axial displacement of all tests did not exceed $4 \mathrm{~mm}$. The same phenomenon occurred in a previous study of the residual strength of a sample from the Shikou landslide area, Japan, and a sample from the Krishnabhir landslide area, Nepal, using the ring shear test [9].

Typically, in a slow shear test under drained conditions, the pore-water pressure is dissipated and assumed to be zero $[9,34]$. However, in this high-speed shear test, the excess 


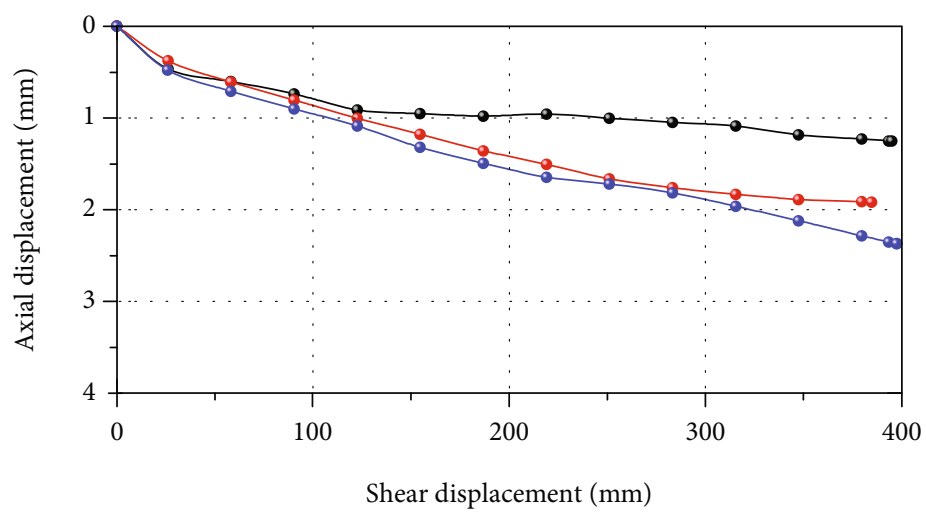

(a)

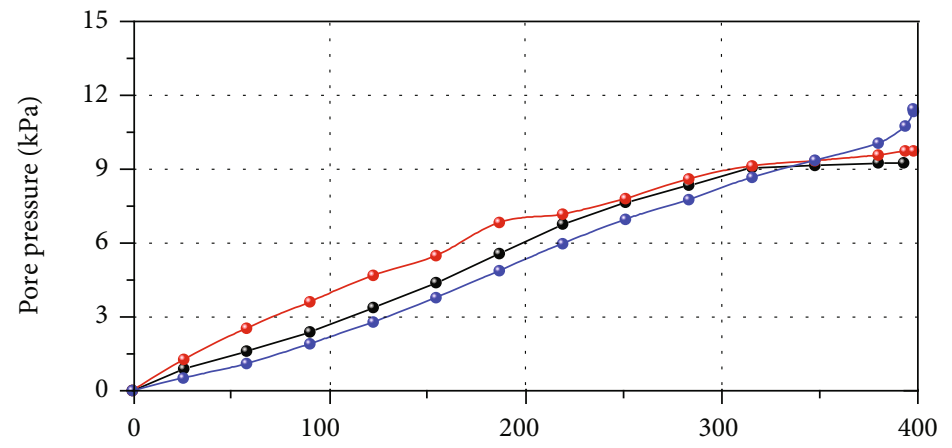

Shear displacement $(\mathrm{mm})$

(b)

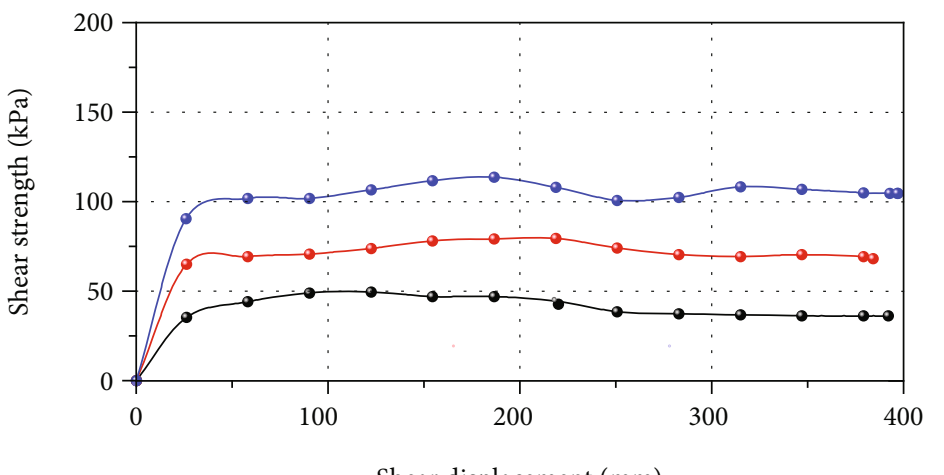

Shear displacement $(\mathrm{mm})$

$$
\begin{aligned}
& \multimap \text { RS_7 100kPa } \\
& \multimap \text { RS_8 } 200 \mathrm{kPa} \\
& \multimap \text { RS_9 } 300 \mathrm{kPa}
\end{aligned}
$$

(c)

FIgURE 5: Results of ring shear tests with a shearing rate of $393 \mathrm{~mm} / \mathrm{min}$.

pore-water pressure had not completely dissipated. The excess pore-water pressure gradually increased with shear displacement (Figure 3(b)). The excess pore-water pressure response was almost the same for the other shearing rate tests (Figures 4(b) and 5(b)). After preconsolidation, the increment of pore-water pressure under different normal stresses was the same.

Figures 3(c), 4(c), and 5(c) show the relationships among shear strength, normal stress, and shearing rate with the progress of shear displacement. All shear strength curves showed a "hardening-stabilizing" process. When normal stress was low $(100 \mathrm{kPa})$, the shear rate had little effect on the peak shear strength and the steady-state shear strength. For example, the peak shear strength at a shear rate of $393 \mathrm{~mm} / \mathrm{min}$ was $49.4 \mathrm{kPa}$, and this value was $63.3 \mathrm{kPa}$ at a shear rate of $131 \mathrm{~mm} / \mathrm{min}$, a difference of only $13.8 \mathrm{kPa}$. However, under high normal stress $(300 \mathrm{kPa})$, the difference in peak shear strength between the high and low shearing rates was $59 \mathrm{kPa}$. Therefore, the higher the normal stress, the greater the influence of the shearing rate on the shear strength. 


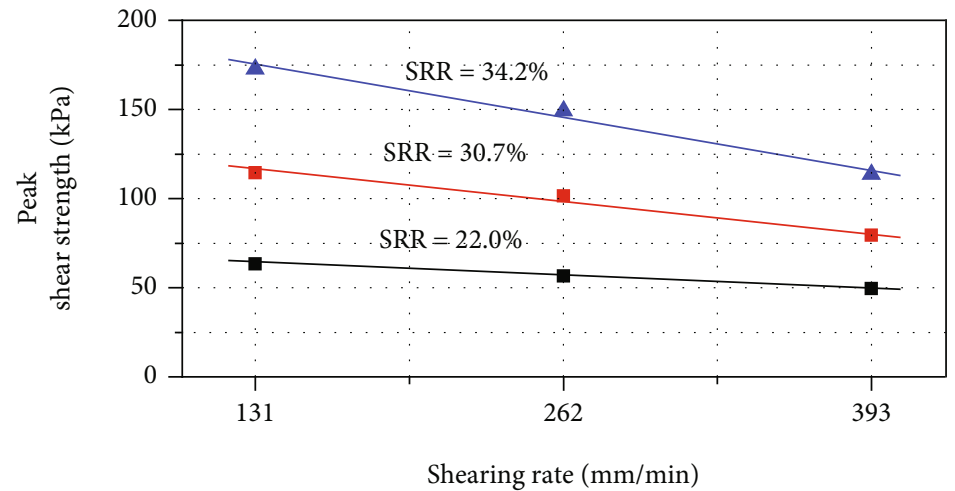

(a)

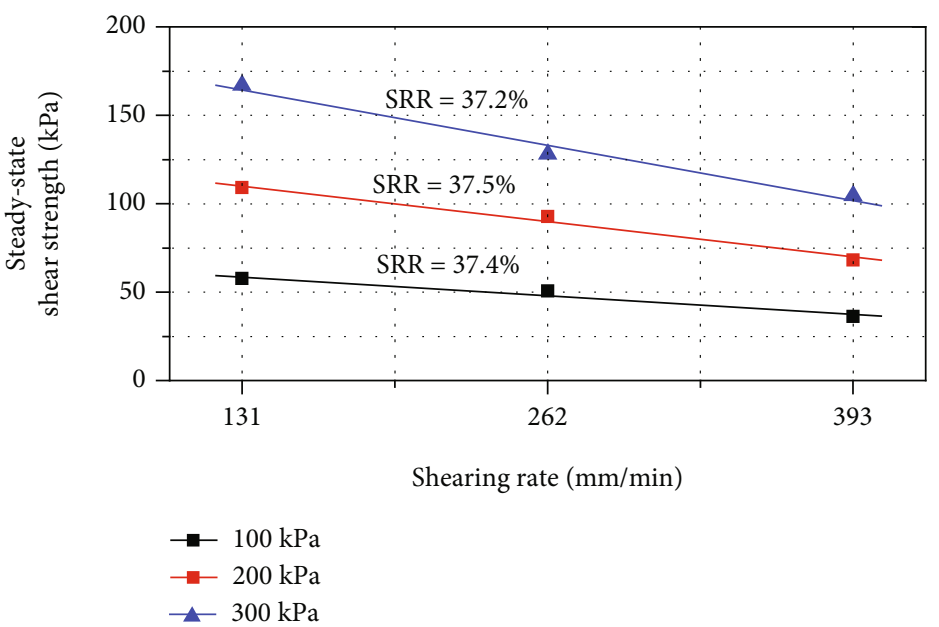

(b)

Figure 6: (a) Peak shear strength and (b) steady-state shear strength versus shearing rate.

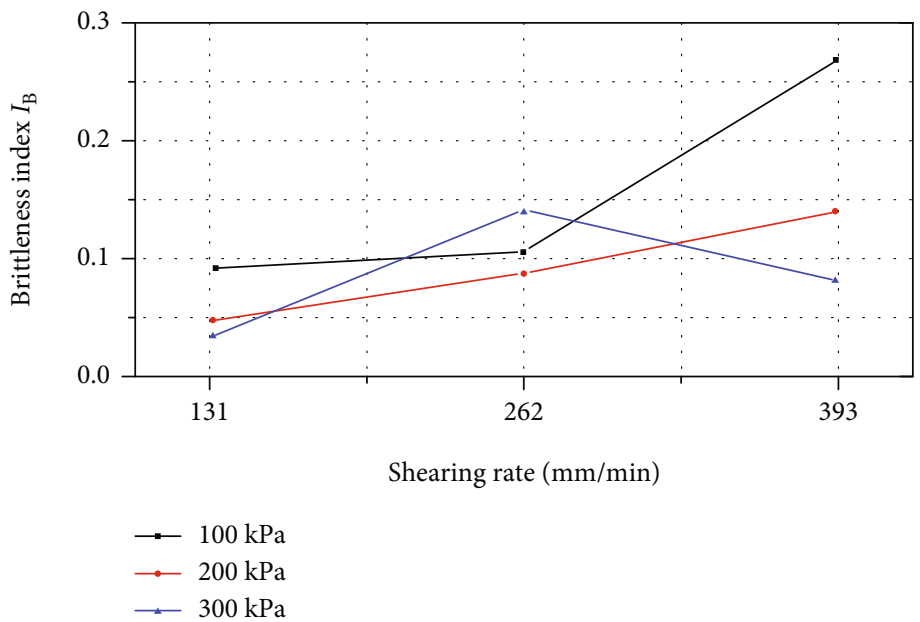

Figure 7: Brittleness index versus shearing rate.

\section{Discussion}

4.1. Effects on Peak Shear Strength and Steady-State Shear Strength. The peak shear strength and steady-state shear strength are plotted in Figure 6 against the shearing rate. Both peak shear strength and steady-state shear strength were relatively higher when the shearing rate was low and vice versa. To explain why the strength decreased with increasing shearing rate, the strength reduction ratio (SRR) was calculated, i.e., the ratio of the strength difference at different shear rates to the strength at a low shear rate. When the shearing rate was increased to $393 \mathrm{~mm} / \mathrm{min}$, the peak 


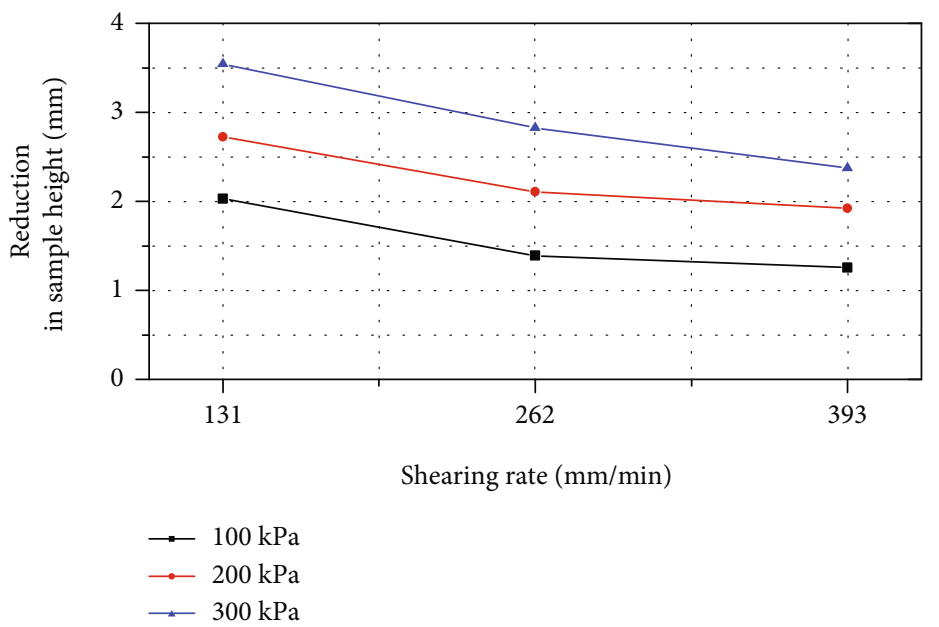

FiguRE 8: Shearing rate versus reduction in sample height after the shear was stopped.

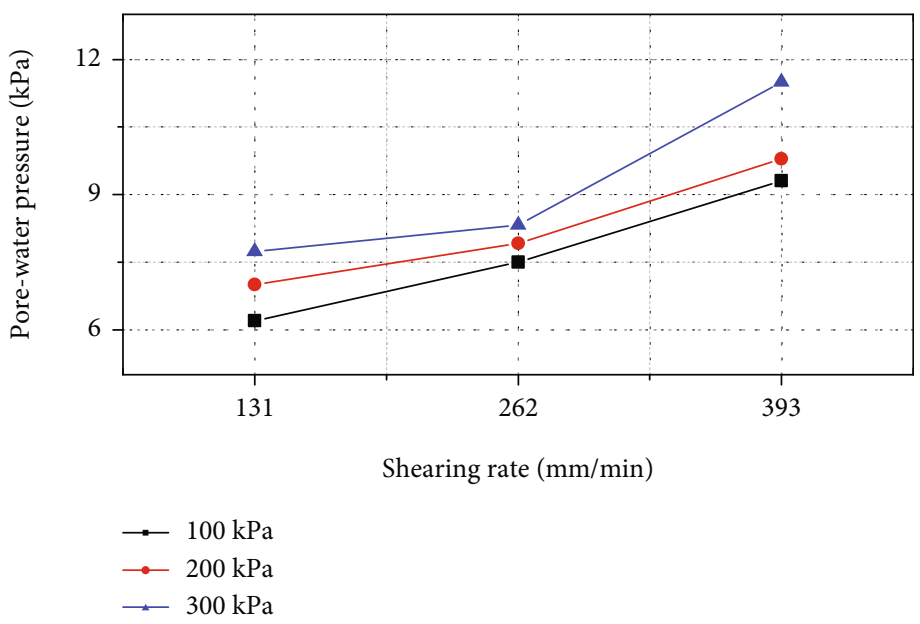

FIGURE 9: Shearing rate versus pore-water pressure after the shear was stopped.

shear strength decreased from $172.7 \mathrm{kPa}$ to $113.7 \mathrm{kPa}$ for samples with normal stress of $300 \mathrm{kPa}$, and the SRR was $34.2 \%$ (Figure 6(a)). However, for samples with normal stress of $100 \mathrm{kPa}$, the SRR was $22.0 \%$. Thus, the shearing rate significantly affected the peak shear strength for samples with high normal stress compared to samples with low normal stress. Relative to the peak shear strength, the shearing rate had a more consistent effect on the steady-state shear strength for samples with different normal stresses, and the SRR was $37.2 \%$ (Figure 6(b)).

4.2. Consequence of Failure. As shown in Figures 3-6, each sample experienced a certain amount of reduction in shear strength after shear failure, which differed for the different samples in the different tests. Here, the brittleness index $\left(I_{\mathrm{B}}\right)[35,36]$ was used to analyze the consequence of shear failure for the different samples. $I_{\mathrm{B}}$ is defined as follows:

$$
I_{\mathrm{B}}=\frac{\left(\tau_{\mathrm{p}}-\tau_{\mathrm{s}}\right)}{\tau_{\mathrm{p}}},
$$

where $\tau_{\mathrm{p}}$ is peak shear strength $(\mathrm{kPa})$ and $\tau_{\mathrm{s}}$ is shear strength at steady state $(\mathrm{kPa})$.

To analyze the relative value between the peak shear strength and shear strength after failure, the minimum shear strength at the steady state was used to calculate $I_{\mathrm{B}}$ for each test. $I_{\mathrm{B}}$ values obtained from different normal stress tests are plotted in Figure 7 against the shearing rate. In all tests, $I_{\mathrm{B}}$ increased with an increase in the shearing rate. However, $I_{\mathrm{B}}$ for the samples with normal stress of $300 \mathrm{kPa}$ and a shearing rate of $393 \mathrm{~mm} / \mathrm{min}$ was in the area without an obvious tendency for change with shearing rate changes, probably due to the increased pore-water pressure (Figure 5(b)). In addition, $I_{\mathrm{B}}$ samples with normal stress of $100 \mathrm{kPa}$ were generally greater than the others. Therefore, $I_{\mathrm{B}}$ increased with an increase in the shearing rate (within the tested low normal stress range). However, for mixed samples of silica sand and loess with loess contents of $10 \%$ by weight, $I_{\mathrm{B}}$ decreased with an increase in the shearing rate [36].

4.3. Effects on the Height Reduction of Samples. During the entire shearing process, axial displacement (reduction in 


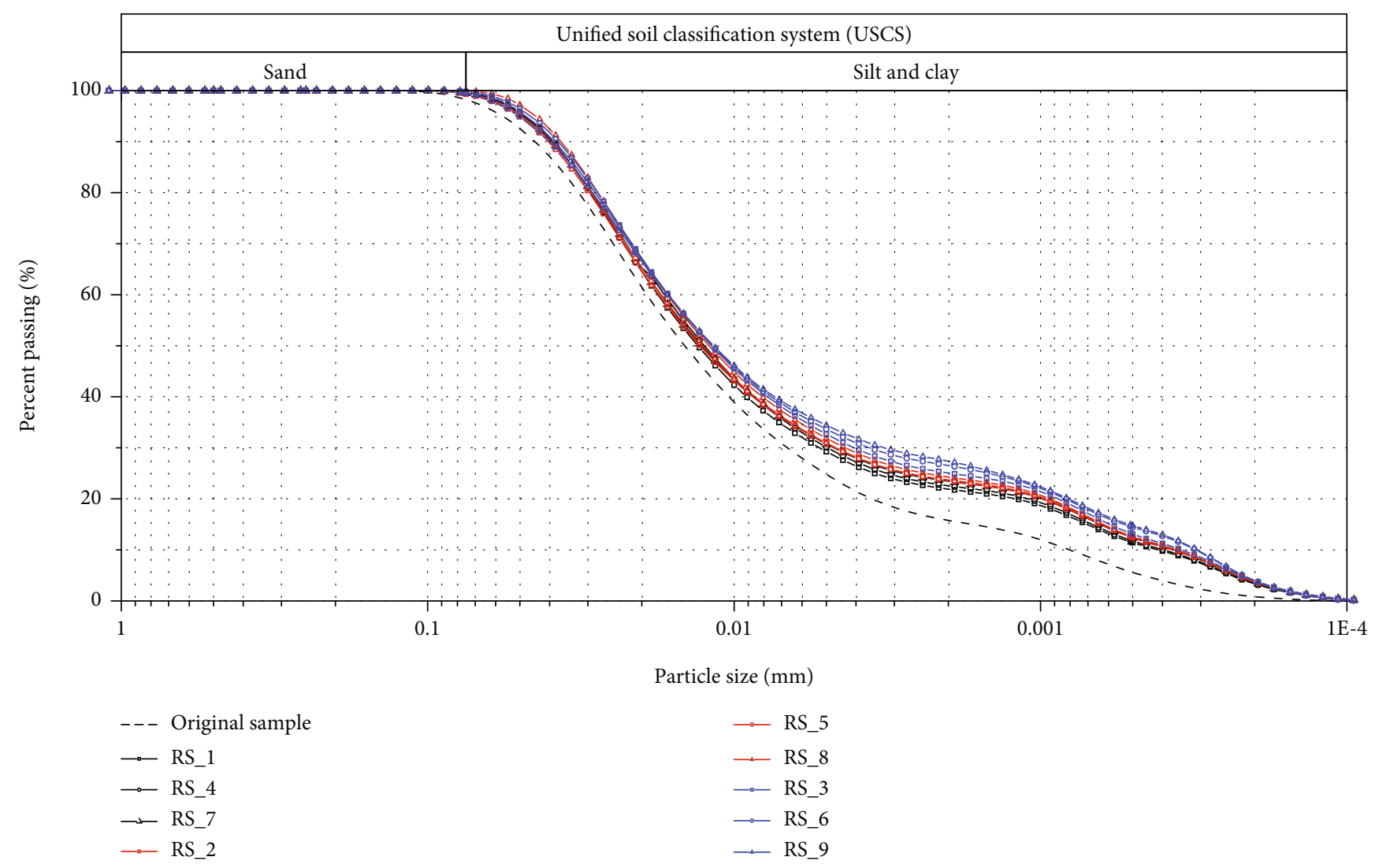

Figure 10: Particle size distributions of samples after the tests.

TABLE 4: Summary of particle size distribution analysis.

\begin{tabular}{lccccccc}
\hline \multirow{2}{*}{ Samples } & \multicolumn{3}{c}{ PSD curve parameters } & \multicolumn{4}{c}{ Grain size } \\
& $D_{10}$ & $D_{30}$ & $D_{50}$ & $D_{60}$ & Sand & Silt & Clay \\
\hline Original sample & 0.80 & 6.70 & 14.51 & 19.29 & 1.8 & 73.4 & 24.8 \\
RS_1 & 0.41 & 5.27 & 13.13 & 17.76 & 0.5 & 70.3 & 29.2 \\
RS_2 & 0.37 & 4.71 & 12.12 & 17.15 & 0.7 & 68.5 & 30.8 \\
RS_3 & 0.35 & 4.06 & 11.85 & 16.39 & 0.2 & 67.1 & 32.7 \\
RS_4 & 0.39 & 4.98 & 12.36 & 17.51 & 0.4 & 69.5 & 30.1 \\
RS_5 & 0.36 & 4.66 & 12.67 & 17.33 & 0.5 & 68.6 & 30.9 \\
RS_6 & 0.31 & 3.63 & 11.76 & 16.42 & 0.3 & 66.1 & 33.6 \\
RS_7 & 0.37 & 4.73 & 12.78 & 17.38 & 0.5 & 68.7 & 30.8 \\
RS_8 & 0.36 & 4.43 & 12.09 & 16.56 & 0.3 & 67.8 & 31.9 \\
RS_9 & 0.31 & 3.24 & 11.68 & 16.48 & 0.2 & 65.4 & 34.4 \\
\hline
\end{tabular}

$D_{10}, D_{30}, D_{50}$, and $D_{60}$ are the particle sizes corresponding to $10,30,50$, and $60 \%$ finer on the cumulative particle size distribution curve, respectively.

sample height) continued to increase (Figures 3(a), 4(a), and $5(\mathrm{a})$ ). The reduction in sample height (when the shear was stopped) is plotted against the shearing rate in Figure 8. Comparison of sample height reductions for all tests found that the low shearing rate test sample underwent a much greater sample height reduction than the high shearing rate test sample. For example, sample RS_3 with a shearing rate of $131 \mathrm{~mm} / \mathrm{min}$ exhibited a greater reduction in sample height than RS_9, due to a greater dissipation of porewater pressure from the shear zone at low shearing rates; however, the variation in the reduction range was within $4 \mathrm{~mm}$.

4.4. Effects on Excess Pore-Water Pressure. Excess pore-water pressure generation and dissipation occurred simultaneously in the shear box. Thus, if the pore-water pressure generation rate exceeded the dissipation rate, positive excess pore-water pressure was built up within the shear zone. Figure 9 depicts the change of excess pore-water pressure with an increase in the shearing rate after the shear was stopped. A higher excess pore-water pressure is generated within the shear zone during the fast shearing process because dissipation relies on the elapsed time, whereas generation is dependent on shear displacement, normal stress, and shearing rate. When other conditions are constant, a faster shearing rate leads to greater shear displacement within a short duration, and greater excess pore-water pressure is generated, subsequently causing a reduction in shear strength. The drainage path for the generated excess pore-water pressure from the shear zone might be around $15 \mathrm{~mm}$ (the thickness of the sample above the shear zone) in the ring shear apparatus, whereas that in the field might be in the order of meters [1]. In the shear zone, a longer drainage path delays the dissipation of pore-water pressure and facilitates the buildup of excess pore-water pressure within the shear zone [36]. 


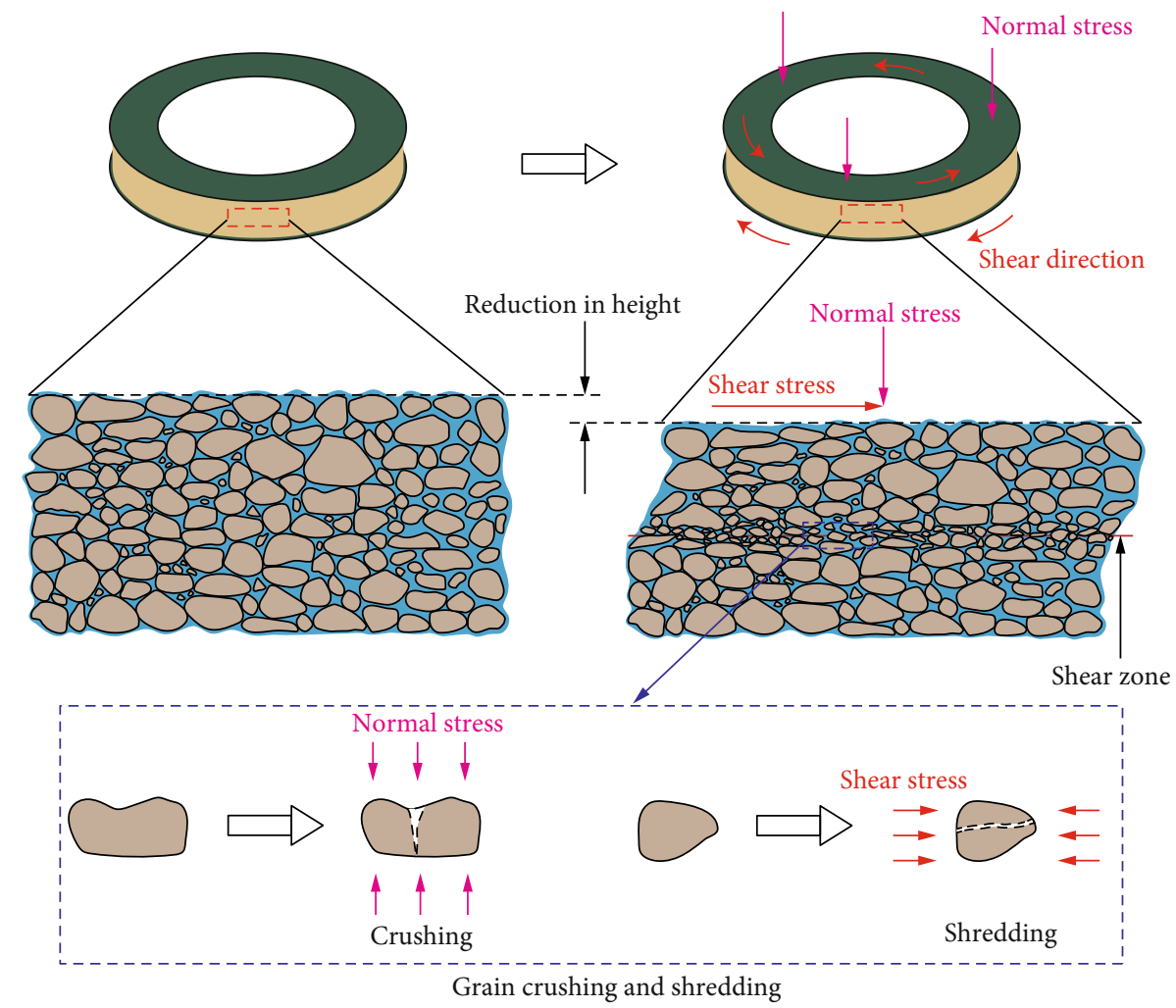

FIgURE 11: Schematic illustration of grain crushing and height reduction.

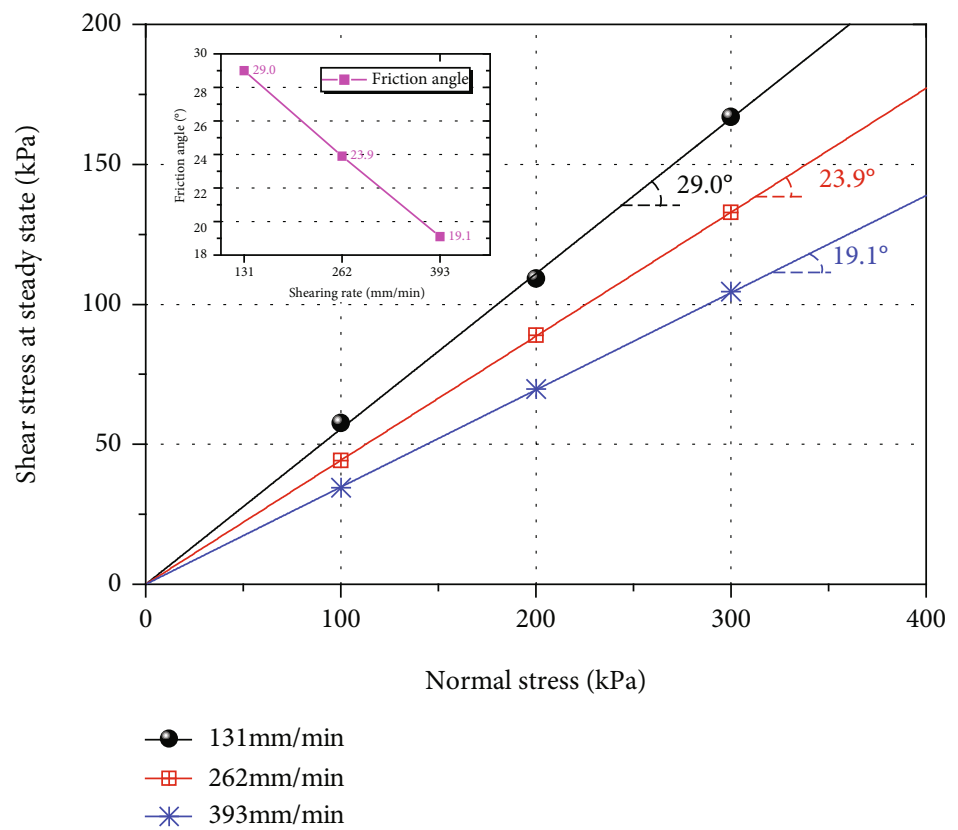

FIGURE 12: Relationship between friction angle and shearing rate.

4.5. Effects on Particle Size. To ascertain the effect of the shearing rate and normal stress on the particle size of the samples, PSD analysis was performed on the samples after the tests, with results shown in Figure 10. Analysis was performed from three aspects: PSD curve parameters, grain size percentage, and grain crushing.
4.5.1. PSD Curve Parameters. Some parameters determined from the PSD curve are listed in Table 4, including $D_{10}$, $D_{30}, D_{50}$, and $D_{60}$. The effective size $\left(D_{10}\right)$ is a good measure for estimating the hydraulic conductivity and drainage through the soil [37] and decreased from $0.80 \mu \mathrm{m}$ (original sample) to $0.31 \mu \mathrm{m}$ (sample with a normal stress of 
$300 \mathrm{kPa}$ and shearing rate of $393 \mathrm{~mm} / \mathrm{min})$. The mean size $\left(D_{50}\right)$ decreased from $14.51 \mu \mathrm{m}$ (original sample) to $11.68 \mu \mathrm{m}$ (sample with a normal stress of $300 \mathrm{kPa}$ and shearing rate of $393 \mathrm{~mm} / \mathrm{min}$ ).

4.5.2. Grain Size Percentage. Based on the PSD curve, the sand, silt, and clay size particles were determined, as shown in Table 4 . The clay percentage increased from $24.8 \%$ (original sample) to $34.4 \%$ (sample with a normal stress of $300 \mathrm{kPa}$ and shearing rate of $393 \mathrm{~mm} / \mathrm{min}$ ), and the silt percentage decreased from $73.4 \%$ (original sample) to $65.4 \%$ (sample with a normal stress of $300 \mathrm{kPa}$ and shearing rate of $393 \mathrm{~mm} / \mathrm{min}$ ). Thus, the shearing rate and normal stress had a great effect on grain size, with a higher shearing rate causing a higher percentage of clay-sized particles.

4.5.3. Grain Crushing. The results in Table 4 and the increase in the percentage of clay size particles implied that soil structure implosion and crushing became more pronounced with increasing normal stress and shearing rates. In the fragile parts of soil particles, normal stress causes soil particles to become crushed, whereas shear stress causes soil particles to become shredded (Figure 11), which might be the reason for the increase in the percentage of clay size particles [38]. This phenomenon has also been shown using the ring shear test on sand samples $[39,40]$.

4.6. Effects on Friction Angle. The friction angle of mobilized soils is the most important factor for predicting landslide movement [20]. For the samples described above, friction angles were determined using the Mohr-Coulomb failure criterion. Figure 12 shows the friction angle-normal stress relationship and the shearing rate. The friction angle of the test sample was $29.9^{\circ}$ at a shear rate of $131 \mathrm{~mm} / \mathrm{min}$; however, when the shearing rate increased to $393 \mathrm{~mm} / \mathrm{min}$, the friction angle dropped to $19.1^{\circ}$. Therefore, as the shearing rate increased, the friction angle decreased. In a study of 40 landslides in the study area, the apparent friction angle (the arctangent relationship between slope height and sliding distance) was approximately $20^{\circ}$ [32].

\section{Conclusions}

A series of ring shear tests was conducted to study the shear behavior of saturated loess with shearing rates of 131, 262, and $393 \mathrm{~mm} / \mathrm{min}$. Based on the test results, the effects of shearing rates on shear behavior under partially drained conditions were discussed. The following conclusions were obtained:

(1) Both peak shear strength and steady-state shear strength were relatively greater when the shearing rate was lower and vice versa. Based on the shearing rate, the maximum SRR of peak shear strength and steady-state shear strength was $34.2 \%$ and $37.2 \%$, respectively

(2) $I_{\mathrm{B}}$ increased with an increase in the shearing rate (within the tested low normal stress range). In addi- tion, $I_{\mathrm{B}}$ samples with a normal stress of $100 \mathrm{kPa}$ were greater than others

(3) The low shearing rate test sample underwent a much greater sample height reduction than the high shearing rate test sample; however, the variation in the reduction range was within $4 \mathrm{~mm}$

(4) A higher excess pore-water pressure was generated within the shear zone during the fast shearing process

(5) Compared with the PSD of the original sample, the PSD of the samples after the tests showed a significant increase in clay content. The soil particles were crushed during the shearing process, and the soil structure implosion became more pronounced with increasing normal stress

\section{Data Availability}

The data used to support the findings of this study are included within the article.

\section{Conflicts of Interest}

The authors declare that they have no conflicts of interest.

\section{Acknowledgments}

This work was supported by the National Natural Science Foundation of China (grant numbers 41602359, 41907255, and 42177155), Key Laboratory of the Northern QinghaiTibet Plateau Geological Processes and Mineral Resources (grant number 2019-KZ-01), and Natural Science Basic Research Plan in Shaanxi Province of China (grant number 2017JQ4019).

\section{References}

[1] Y. Leng, J. Peng, Q. Wang, Z. Meng, and W. Huang, "A fluidized landslide occurred in the Loess Plateau: a study on loess landslide in South Jingyang tableland," Engineering Geology, vol. 236, pp. 129-136, 2018.

[2] Y. Li and J. Zhao, Loess and Loess Geohazards in China, 1st, CRC Press, Boca Raton, 2017.

[3] J. Zhuang, J. Peng, G. Wang, I. Javed, Y. Wang, and W. Li, "Distribution and characteristics of landslide in Loess Plateau: a case study in Shaanxi province," Engineering Geology, vol. 236, pp. 89-96, 2018.

[4] X. Qi, Q. Xu, and F. Liu, "Analysis of retrogressive loess flowslides in Heifangtai, China," Engineering Geology, vol. 236, pp. 119-128, 2018.

[5] A. W. Skempton, "Bedding-plane slip, residual strength and the Vaiont Landslide," Géotechnique, vol. 16, no. 1, pp. 8284, 1966.

[6] W. Yuan, W. Fan, C. Jiang, and X. Peng, "Experimental study on the shear behavior of loess and paleosol based on ring shear tests," Engineering Geology, vol. 250, pp. 11-20, 2019.

[7] K. Sassa, G. Wang, and H. Fukuoka, "Performing undrained shear tests on saturated sands in a new intelligent type of ring 
shear apparatus," Geotechnical Testing Journal, vol. 26, no. 3, pp. 257-265, 2003.

[8] B. Lian, J. Peng, X. Wang, and Q. Huang, "Moisture content effect on the ring shear characteristics of slip zone loess at high shearing rates," Bulletin of Engineering Geology and the Environment, vol. 79, no. 2, pp. 999-1008, 2020.

[9] D. R. Bhat, Ed.R. Yatabe, "Effect of shearing rate on residual strength of landslide soils," in Engineering Geology for Society and Territory, D. R. Bhat, D. Giordan, G. B. Crosta, J. Corominas, R. Azzam, J. Wasowski, N. Sciarra, and , Eds., vol. 2, pp. 12111215, Springer International Publishing, Cham, 2015.

[10] N. T. Duong, M. Suzuki, and N. van Hai, "Rate and acceleration effects on residual strength of kaolin and kaolin- bentonite mixtures in ring shearing," Soils and Foundations, vol. 58, no. 5, pp. 1153-1172, 2018.

[11] S.-W. Jeong and S.-S. Park, "Effect of the surface roughness on the shear strength of granular materials in ring shear tests," Applied Sciences, vol. 9, no. 15, p. 2977, 2019.

[12] H.-M. Lin, J.-H. Wu, and E. Sunarya, "Consolidated and undrained ring shear tests on the sliding surface of the Hsien-du-shan landslide in Taiwan," Geofluids, vol. 2018, 12 pages, 2018.

[13] I. Tomasetta, D. Barletta, and M. Poletto, "The high temperature annular shear cell: a modified ring shear tester to measure the flow properties of powders at high temperature," Advanced Powder Technology, vol. 24, no. 3, pp. 609-617, 2013.

[14] Z. Zhongqiong, W. Qingbai, J. Guanli, G. Siru, C. Ji, and L. Yongzhi, "Changes in the permafrost temperatures from 2003 to 2015 in the Qinghai-Tibet Plateau," Cold Regions Science and Technology, vol. 169, p. 102904, 2020.

[15] Z.-Q. Zhang, Q.-B. Wu, M.-T. Hou, B.-W. Tai, and Y.-K. An, "Permafrost change in Northeast China in the 1950s-2010s," Advances in Climate Change Research, vol. 12, no. 1, pp. 1828, 2021.

[16] X. Zhang, E. Zhai, Y. Wu, D. Sun, and Y. Lu, “Theoretical and numerical analyses on hydro-thermal-salt-mechanical interaction of unsaturated salinized soil subjected to typical unidirectional freezing process," International Journal of Geomechanics, vol. 21, no. 7, 2021.

[17] A. W. Skempton, "Residual strength of clays in landslides, folded strata and the laboratory," Géotechnique, vol. 35, no. 1, pp. 3-18, 1985.

[18] T. E. Tika and J. N. Hutchinson, "Ring shear tests on soil from the Vaiont landslide slip surface," Géotechnique, vol. 49, no. 1, pp. 59-74, 1999.

[19] O. Hunger and N. R. Morgenstern, "High velocity ring shear tests on sand," Géotechnique, vol. 34, no. 3, pp. 415-421, 1984.

[20] K. Sassa and H. Fukuoka, "Measurement of the internal friction angle of soils during motion by the high-speed ring shear apparatus," Landslides, vol. 29, no. 4, pp. 1-8_1, 1993.

[21] T. E. Tika, P. R. Vaughan, and L. J. L. J. Lemos, "Fast shearing of pre-existing shear zones in soil," Géotechnique, vol. 46, no. 2, pp. 197-233, 1996.

[22] E. Akis, A. Mekael, and M. T. Yilmaz, "Investigation of the effect of shearing rate on residual strength of high plastic clay," Arabian Journal of Geosciences, vol. 13, no. 2, 2020.

[23] S. Wahyudi, J. Koseki, T. Sato, and G. Chiaro, "Multiple-liquefaction behavior of sand in cyclic simple stacked-ring shear tests," International Journal of Geomechanics, vol. 16, no. 5, 2016.
[24] Y. Hong, G. Yu, Y. Wu, and X. Zheng, "Effect of cyclic loading on the residual strength of over-consolidated silty clay in a ring shear test," Landslides, vol. 8, no. 2, pp. 233-240, 2011.

[25] I. B. Gratchev and K. Sassa, "Shear strength of clay at different shear rates," Journal of Geotechnical and Geoenviromental Engineering, vol. 141, no. 5, p. 06015002, 2015.

[26] Y. Jiang, G. Wang, and T. Kamai, "Fast shear behavior of granular materials in ring-shear tests and implications for rapid landslides," Acta Geotechnica, vol. 12, no. 3, pp. 645-655, 2017.

[27] H. Fukuoka, K. Sassa, and G. Wang, "Influence of shear speed and normal stress on the shear behavior and shear zone structure of granular materials in naturally drained ring shear tests," Landslides, vol. 4, no. 1, pp. 63-74, 2007.

[28] S. Wang, W. Wu, W. Xiang, and Q. Liu, "Shear behaviors of saturated loess in naturally drained ring-shear tests," in Recent Advances in Modeling Landslides and Debris Flows, W. Wu, Ed., pp. 19-27, Springer International Publishing, Cham, 2015.

[29] L. XU, F. DAI, L. G. THAM, X. TU, and Y. JIN, "Landslides in the transitional slopes between a loess platform and river terrace, northwest China," Environmental and Engineering Geoscience, vol. 17, no. 3, pp. 267-279, 2011.

[30] Z. Duan, W.-C. Cheng, J.-B. Peng, M. M. Rahman, and H. Tang, "Interactions of landslide deposit with terrace sediments: perspectives from velocity of deposit movement and apparent friction angle," Engineering Geology, vol. 280, p. 105913, 2021.

[31] J. Peng, P. Ma, Q. Wang et al., "Interaction between landsliding materials and the underlying erodible bed in a loess flowslide," Engineering Geology, vol. 234, pp. 38-49, 2018.

[32] Z. Duan, W.-C. Cheng, J.-B. Peng, Q.-Y. Wang, and W. Chen, "Investigation into the triggering mechanism of loess landslides in the south Jingyang platform, Shaanxi province," Bulletin of Engineering Geology and the Environment, vol. 78, no. 7, pp. 4919-4930, 2019.

[33] ASTM D2487-17e1, Standard Practice for Classification of Soils for Engineering Purposes (Unified Soil Classification System), ASTM International, West Conshohocken, PA, 2017.

[34] C. Ma, H. Zhan, T. Zhang, and W. Yao, "Investigation on shear behavior of soft interlayers by ring shear tests," Engineering Geology, vol. 254, pp. 34-42, 2019.

[35] A. W. Bishop, "Progressive failure with special reference to the mechanism causing it," in Proceedings of the Geotechnical Conference on Shear Strength Properties of Natural Soils and Rocks, pp. 142-150, Norwegian Geotechnical Institute, Oslo, Norway, 1967.

[36] G. Wang, K. Sassa, H. Fukuoka, and T. Tada, "Experimental study on the shearing behavior of saturated silty soils based on ring-shear tests," Journal of Geotechnical and Geoenviromental Engineering, vol. 133, no. 3, pp. 319-333, 2007.

[37] B. M. Das and K. Sobhan, Principles of Geotechnical Engineering, Cengage Learning, Australia, Ninth edition, 2018.

[38] S. Li, H. Liang, H. Li, J. Ma, and B. Li, "Minimum void ratio model establishing of tailings and determination of optimal void ratio," Geofluids, vol. 2021, Article ID 8619121, pp. 1-15, 2021.

[39] H. Wei, T. Zhao, J. He, Q. Meng, and X. Wang, "Evolution of particle breakage for calcareous sands during ring shear tests," International Journal of Geomechanics, vol. 18, no. 2, p. 04017153, 2018.

[40] A. Sadrekarimi and S. M. Olson, "Particle damage observed in ring shear tests on sands," Canadian Geotechnical Journal, vol. 47 , no. 5 , pp. $497-515,2010$. 